\title{
Domínios do café: ferrovias, exportação e mercado interno em São Paulo (1888-1917) ${ }^{1}$ Pedro Geraldo Tosi ${ }^{2}$ Rogério Naques Faleiros ${ }^{3}$
}

\section{Resumo}

Não obstante o peso decisivo das receitas geradas pelo café para os balanços financeiros das ferrovias paulistas entre 1888 e 1917 , e a centralidade da atividade cafeeira na economia paulista de então, discute-se neste artigo a especialização relativa ao nível da produção verificada em São Paulo e a questão dos fretes das ferrovias neste cenário. Parte-se da ideia de que a cafeicultura, em seu desenvolvimento, demandava a diversificação de culturas agrícolas, pois as unidades básicas de produção - as fazendas de café - não se caracterizavam unicamente pela monocultura, sendo que os nexos entre uma produção voltada à exportação e outra voltada ao mercado interno davam-se nas relações de trabalho estabelecidas entre contratantes e contratados, e nas formas pelas quais os fazendeiros expropriavam aqueles que se subordinavam aos seus interesses. Verifica-se no caso estudado o aumento simultâneo das quantidades de café e de alimentos transportadas e transacionadas pela Cia. Mogiana nos marcos da periodização proposta; porém, percebe-se estreita dependência em relação à receita gerada pelo transporte de café. Aponta-se, ainda, a especialização absoluta ao nível do crédito e da circulação (transportes) que caracterizavam este complexo econômico.

Palavras-chave: Cafeicultura; Ferrovias; CMEF; Produção de alimentos; São Paulo.

\section{Abstract \\ Coffee economy: railroads, export and the internal market in São Paulo (1888-1917)}

Notwithstanding the decisive weight of values generated by coffee for the financial statements of the São Paulo's railroads between 1888 and 1917, and to the importance of the coffee in this economy, we argues in this article about the relative specialization in agriculturist production verified in São Paulo's lands and the question of the freights of the railroads in this conditions. Our idea is that coffee activity, in its development, demanded the diversification of agricultural cultures, therefore the basic units of production - the coffee farms - were not characterized solely by the cultivation of coffee, being that the nexuses between a production come back to the exportation and another come back to the internal market were given in the relations of work established between employers and employees, and in the forms by which the farmers expropriated its subordinate. The simultaneous increase of the amounts of coffee is verified in the studied case and of foods carried and done business for the Cia. Mogiana in landmarks of the period proposal; however, narrow_dependence in relation to the values generated for the coffee transport is perceived. It is pointed, still, the absolute

(1) Trabalho recebido em 19 de agosto de 2009 e aprovado em 4 de março de 2010.

(2) Professor da Faculdade de História, Direito e Serviço Social da Universidade Estadual Paulista, Franca, SP, Brasil. E-mail: pgtosi@uol.com.br.

(3) Professor Adjunto do Departamento de Economia do Centro de Ciências Jurídicas e Econômicas da Universidade Federal do Espírito Santo, Vitória, ES, Brasil. E-mail: rogerionaques@yahoo.com.br.

Economia e Sociedade, Campinas, v. 20, n. 2 (42), p. 417-442, ago. 2011. 
specialization to the level of the credit and the circulation (transports) that characterized this economic complex.

Keywords: Coffee economy; Railroads; CMEF; Food production; São Paulo. JEL N56, N96.

\section{Introdução}

O paradigma interpretativo desenvolvido nos anos noventa tem chamado a atenção para a importância, senão predominância, das atividades voltadas ao mercado interno para a formação da econômica nacional. Os trabalhos empreendidos por João Luiz Fragoso e Manolo Florentino ${ }^{4}$, estribados em evidências empíricas, questionaram a partir do caso do Rio de Janeiro, entre fins do século XVIII e início do século XIX, os modelos interpretativos baseados nas noções de Exclusivo Metropolitano e Antigo Regime, que destacavam a predominância na realidade colonial (e posteriormente nacional) de toda uma estrutura voltada à produção especializada destinada unicamente à exportação. No horizonte deste paradigma está a crítica às análises pautadas no trinômio latifúndio, escravidão e monocultura, desvelando uma realidade econômica e social mais complexa do que supunha a noção de capital residente ${ }^{5}$.

Paulatinamente, direta ou indiretamente, esta visão tem inspirado estudos sobre o complexo econômico paulista; aliás, a predominância de tal visão distancia-se cada vez mais da noção de complexo cafeeiro, desenvolvido no âmbito da "Escola de Campinas" economia cafeeira têm sido a tônica de novos trabalhos sobre o café, elegendo-se um município, uma região ou mesmo uma estrada de ferro como objeto de análise. Assim, contribui-se cada vez mais para o entendimento destas particularidades revelando avanços no que se refere a temas como as relações de trabalho, a industrialização, as companhias ferroviárias e a urbanização, por exemplo.

Com a "descoberta" de novas fontes ${ }^{7}$ e o desenvolvimento de novos métodos de pesquisa temos avançado rapidamente no entendimento e na tentativa

(4) Síntese destes trabalhos encontra-se em Fragoso e Florentino (1998). Cabe salientar que o comércio interno de abastecimento já era tema consagrado pela historiografia mesmo antes das abordagens acima citadas. Vejam-se os trabalhos de Zemella (1951); Linhares e Silva, Francisco C. T. da (1980); Lenharo (1993).

(5) Neste sentido, considerar também os trabalhos de Schwartz (1988) e de Alencastro (2000).

(6) Referimo-nos aqui, evidentemente, ao texto de Wilson Cano "Raízes da concentração industrial em São Paulo" (1998). Em suas palavras: "Quando se tenta compreender o processo dinâmico de crescimento de uma economia, torna-se absolutamente necessário analisar que partes principais a compõem, como atua cada uma delas nesse processo de crescimento, e que graus e tipo de inter-relacionamentos entre elas possibilitam o surgimento de um conjunto econômico integrado. A esse conjunto de atividades sobre o qual atua um certo número de variáveis independentes ou não ao conjunto - creio que se lhe pode chamar de 'complexo econômico"'(p. 29).

(7) Vide a utilização de fontes até então pouco exploradas como os inventários, relatórios de companhias ferroviárias, relatos de viajantes e livros cartoriais. 
de reconstituição das várias condições vividas dentro da cafeicultura paulista. Hoje, contudo, qual é a nossa capacidade de empreendermos um esforço de síntese? Em que ponto da interpretação é possível articular as novas informações desveladas pelos estudos atuais com a produção bibliográfica dita "tradicional"? Vale dizer, em que ponto a produção voltada ao mercado interno, notadamente a pecuária e a produção de gêneros alimentícios, se articula com a cafeicultura? Será que não se articulam? Qual a importância da ferrovia na viabilização e na diversificação da produção paulista? Antes de arriscarmos algumas respostas, citemos alguns estudos recentemente desenvolvidos acerca da produção de alimentos e da cafeicultura paulista em suas múltiplas perspectivas.

\section{0 "mosaico" paulista}

Vários estudos ressaltam a existência de uma produção voltada ao mercado interno no interior paulista ${ }^{8}$. Exemplo disso são os trabalhos de Rosane Messias e Lélio Oliveira. Messias, em estudo que versa sobre os municípios de Araraquara e São Carlos, destaca que esta região (os Campos de Araraquara)

diferentemente do que se imaginava, não eram apenas paragens e freguesias fragilmente erguidas longe dos mais antigos e prósperos nucleamentos urbanos ou agrários. Destinadas inicialmente a atender viajantes e tropeiros, com uma população instável e itinerante, dedicada ao cultivo de roças de subsistência e criação de gado, elas foram se transformando ao longo do século XIX e consolidando uma economia própria, como uma economia diversificada, próspera, com uma dinâmica integrada às necessidades do mercado interno" (Messias, 2003, p. 48, grifos nossos).

Embora o trabalho da autora se estenda até 1888, não abarcando o auge da cafeicultura nesta região do estado, a partir da descrição de uma propriedade agrícola de 1915 podemos imaginar que estas atividades de "subsistência"9 coexistiram com a atividade cafeeira. A fazenda Atalaia, de propriedade de Hermínia Ferraz Borba, é assim descrita no Álbum para o ano de 1915:

Têm a área de 600 alqueires, na quase totalidade de terras roxas, dos quais 240 plantados com 436.000 pés de café; 100 em pasto com 100 cabeças de gado bovino,

(8) Não necessariamente destacando uma produção de alimentos destinada ao mercado interno, pois é temerária a utilização do termo "mercado" em época tão remota, o trabalho de Sérgio Buarque de Holanda destaca a existência de hábitos e costumes que envolviam a plantação e o fabrico da farinha de mandioca, do milho e do trigo, como também de outras culturas agrícolas, que remontam aos primórdios da colonização de Piratininga. Ver Caminhos e fronteiras (1994), especialmente os capítulos da segunda parte, "Técnicas Rurais". A primeira edição foi publicada em 1957.

(9) Não concordamos com o termo "lavouras de subsistência", pois nos dá a falsa ideia de que eram cultivadas unicamente para tal finalidade. O termo "produção mercantil de alimentos" nos parece mais adequado, pois com o desenvolvimento do complexo econômico paulista (e mesmo antes) estas atividades foram adquirindo um caráter preponderantemente mercantil. Caio Prado Jr. se utiliza abertamente do termo "lavouras de subsistência" referindo-se às demais culturas agrícolas que não aquelas destinadas à exportação. Talvez daí derive o equívoco. 
45 muares, 30 éguas, 06 cavalos e 01 jumento, 60 alqueires para plantação de cereais e 200 para extração de madeiras (Araraquara, 1915, p. 167, grifos nossos).

Evidentemente uma parcela da produção de cereais destinava-se ao consumo dos colonos, porém, veremos adiante que estas produções também entravam no "giro mercantil", muitas das quais embarcadas e desembarcadas nas estações ferroviárias.

O próprio município de São Carlos, eminente centro produtor que apresentava uma das maiores médias de cafeeiros por propriedade do interior paulista (cerca de oitenta mil cafeeiros em 1920) ${ }^{10}$, apresentava destacada produção de alimentos. Segundo a Estatística Agrícola do município de São Carlos do Pinhal, organizada pelo Clube da Lavoura em 1899, colheram-se as seguintes quantidades: um milhão e duzentas mil arrobas de café, 450.000 alqueires (50 litros) de milho, 7.000 de arroz, 44.000 de feijão, além de batata inglesa, batata doce, fumo e mandioca ${ }^{11}$. A estatística alerta que mesmo com esta produção de alimentos o município ainda "importava" "12 arroz, toucinho, farinha de trigo, aguardente, açúcar, carne seca e bacalhau. Em São Carlos a cafeicultura ocupava uma área de 12.523 alqueires em 1905, enquanto a cultura do milho ocupava 9.252,5 alqueires e o feijão 4.061,25 alqueires, revelando certo grau de diversificação da agricultura.

Dificilmente se encontraria na região de Araraquara e São Carlos, como em quase todo interior paulista ${ }^{13}$, fazendas unicamente especializadas na produção de café. Nas fazendas de maior dimensão uma parte das terras sempre era destinada à produção de "cereais". Lá também, ao lado dos terreiros, das tulhas e das casas de máquinas, avistavam-se monjolos para pilar o milho, moinhos para a produção de fubá, pilão para "socar" o arroz, pastos para as criações e carroças para transportar toda esta produção para as vendas, cidades e estações. Nos sítios e chácaras algumas partes das terras, como também as próprias fileiras do cafezal, destinavam-se ao plantio de outros gêneros, tendendo esta faixa de propriedades mais claramente à policultura, resguardando-se, evidentemente, a dominante posição da cafeicultura. O café e as outras culturas conviveram e se viabilizaram mutuamente.

Lélio Oliveira, em estudo que versa sobre a região de Franca, situada no extremo nordeste do estado, destaca que a produção de alimentos e a criação de

(10) Camargo (1981, p. 92)

(11) "Estatística agrícola do município de São Carlos do Pinhal”, organizada pelo Clube da Lavoura em 1899 (Truzzi $(2004$, p. 50$)$.

(12) Termo comumente utilizado no interior paulista à época, não se refere especificamente ao comércio entre dois países, mas também ao fluxo de entrada de produtos oriundos de outros municípios.

(13) Trabalhos como os de André Argolo Ferrão (2004) para a região de Campinas, e o de Vladimir Benincasa (2003) para a região de Araraquara indicam esta fusão entre a arquitetura do café e elementos e construções próprias de outras atividades agrícolas e criatórias. 
animais, atividades pretéritas à cafeicultura, foram dinamizadas em função da aproximação dos trilhos da Companhia Mogiana de Estradas de Ferro (doravante CMEF ou Mogiana), ampliando-se consideravelmente as possibilidades de negociação destes gêneros e das rezes criadas ou simplesmente "engordadas" "14 na região. O autor ressalta também o caráter "híbrido" de muitas das propriedades rurais ali sediadas, voltadas tanto para a produção dirigida à exportação quanto à produção dirigida ao mercado interno. No inventário de Joaquim Garcia Lopes da Silva, destacado produtor local, lista-se uma estrutura assim discriminada: "três paióis, sendo um para chiqueiro, um rancho para porcos, dois monjolos, um monjolo de fubá, uma cocheira com dependências, uma máquina de beneficiar café e arroz, tulha para café e rancho para carros de boi" (Oliveira, 2006, p. 94). $\mathrm{Na}$ descrição dos bens, encontrava-se também “cem sacos de feijão (200\$000), setenta carros de milho (1:920\$000), quinhentos sacos de arroz em casca (5:500\$000), quatro mil arrobas de café $(20: 000 \$ 000)$ e mais doze mil arrobas deste mesmo produto (60:000\$000) pendentes da safra passada" (Ibidem, p. 94). Assim como nos casos acima citados, as sacas de café atingiam maior valor unitário e absoluto; porém, o que buscamos salientar neste momento é a existência de uma produção de alimentos em regiões de cafeicultura ${ }^{15}$.

O estudo de Flávia Arlanch de Oliveira, que versa sobre o município de Jaú, destaca a recorrência, nesta região, de características muito próximas às acima citadas: a ausência de uma maior especialização das unidades produtoras, produção voltada ao mercado interno que precede e posteriormente convive com a cafeicultura, e a manutenção das atividades criatórias (em maior ou menor grau, dependendo da região). Segundo a autora, verifica-se com a aproximação dos trilhos da Paulista (1887) a diminuição da área destinada ao plantio de fumo e de cana-de-açúcar (provavelmente por conta da inviabilidade do plantio conjugado entre as ruas dos cafeeiros) que paulatinamente foram substituídas pelo café, ainda que destaque-se também a manutenção e ampliação da produção de gêneros que circulavam prioritariamente nos mercados locais e extraordinariamente em mercados mais distantes, tais como arroz, milho e feijão. Oliveira nota que a

(14) Os campos e pastos desta região são assim descritos pelos "Questionários sobre as condições da agricultura dos 173 municípios do estado de São Paulo", realizado pelo Serviço de Inspeção e defesa agrícolas do Ministério da Agricultura, Indústria e Comércio de 1913: "nos campos: mácega, capim lanceta, etc.; nos pastos: capim gordura roxo e Jaraguá; há campos ervados; é célebre o capim gordura de Franca, cuja semente é tão espalhada pelo Brasil, com tantas vantagens para os agricultores, que muito o procuram". Agradecemos a gentileza de Henry Marcelo Martins Silva que nos proporcionou o contato com esta documentação.

(15) Aparentemente, tais características são perceptíveis nas demais áreas de cafeicultura, como podemos observar neste trecho extraído de Mônica Ribeiro de Oliveira: "A existência de lavouras de alimentos no interior de fazendas cafeeiras deve ser considerada um traço estrutural do sistema agrário cafeicultor (...) a presença destas lavouras implementava a capacidade reprodutiva das fazendas que precisavam recorrer menos ao mercado para a satisfação das necessidades de subsistência da unidade". O estudo da autora trata de alguns municípios da zona da mata mineira. Ver Oliveira, M. R. (2000). Ver também o estudo de João Luís Fragoso (1983). 
região de Jaú apresentava uma expressiva heterogeneidade fundiária em função da diversidade de tipos de solos que ali se encontravam. Nas porções com predominância da terra roxa estabeleceram-se as maiores fazendas, onde, segundo a autora, "a racionalidade da organização do espaço produtivo em termos capitalistas estava mais presente" (Oliveira, F. A. 1999. p. 153). Já nas paragens jauenses com solos de pior qualidade predominavam as pequenas e médias fazendas, mais diretamente propensas à policultura, mas onde também se cultivava o café.

A partir de estudos que não versam diretamente sobre a cafeicultura, mas que tratam de outras regiões paulistas, podemos imaginar um caráter econômico semelhante aos acima citados. É o caso, por exemplo, das regiões que se ligavam indiretamente às feiras de muares de Sorocaba, tais como Botucatu e Itapetininga, que foram aos poucos se destacando na produção de alimentos voltada ao mercado interno, prioritariamente ao abastecimento das tropas - mas também destinada ao quadrilátero do açúcar - como também se constituindo como interessante rota de desvio dos impostos cobrados nas barreiras comerciais, contrabandeando as mulas que vinham do sul para Rio Claro e Franca, entrepostos situados a norte (Di Creddo, 2003, p. 59). A recorrência de pequenos plantéis de escravos, destacada por César Múcio Silva, corrobora a hipótese de uma formação econômica com predominância de pequenas propriedades com baixo grau de especialização também nas regiões ao sul do estado (Silva, 2004), definindo um tipo de sociedade e de atividade econômica com a qual a cafeicultura iria se defrontar futuramente, no final do século XIX e início do século XX.

O estudo de Hilário Domingues Neto evidencia outra região paulista onde a produção voltada ao mercado interno teve destaque. Trata-se do trecho fluvial da Companhia Paulista de Estradas de Ferro e Navegação que operava no rio MogiGuaçu, num percurso de duzentos quilômetros, cortando as regiões de Porto Ferreira, Santa Rita do Passa Quatro e estendendo-se ao norte do estado, nas proximidades de Barretos. Domingues Neto destaca que a economia que se desenvolvia no vale do Mogi-Guaçu direcionava-se mais diretamente para uma economia de abastecimento interno com base na agricultura e na pecuária, uma vez que pelos seguidos anos de operação do trecho fluvial (1890-1903) o tráfego de outras mercadorias (inclusive o sal) fora mais substancial do que o de café (Domingues Neto, 2001).

O que se verifica na Província de São Paulo em período precedente à cafeicultura em grandes escalas é a convivência e inter-relação de diferentes circuitos e produções, formando um "mosaico" e um cenário marcado pela diversidade. Casa Branca $^{16}$, por exemplo, fora destacada praça comercial de

(16) Ver Santos (1980). 
escravos vindos de Minas Gerais, alocados prioritariamente nas regiões produtoras de açúcar de Campinas, Piracicaba, Porto Feliz e Itu, que por sua vez demandavam parcela do comércio de muares provenientes do sul e transacionados em Sorocaba ${ }^{17}$, utilizados para transporte e tração. Franca ${ }^{18}$ polarizava o comércio de sal no centro-oeste brasileiro e, em sentido contrário, recebia e despachava boa parte do "gado em pé" vindo de Goiás e de Uberaba com destino ao Rio de Janeiro (capital), à cidade de São Paulo e a Campinas, pela antiga "estrada dos goiazes". Barretos, ao norte do estado, destacava-se nas atividades criatórias e de invernadas polarizando o comércio do gado proveniente do Taboado e do atual triângulo mineiro, cortando também os Campos de Araraquara. No extremo oeste, nas regiões posteriormente cortadas pelas estradas de ferro da Sorocabana e da Noroeste do Brasil, verificava-se uma vida econômica menos intensa, porém já tocada pelos negociantes, que se valiam do apresamento de indígenas utilizando o caminho das Monções. No Vale do Paraíba paulista já se verificava uma maior especialização na produção de café, capitaneada pelo capital fluminense e ainda cultivado com mão-de-obra cativa, e a capital do estado aos poucos ia se tornando uma espécie de polo centrípeto de toda esta formação econômica - função que ocupará definitivamente com o advento das ferrovias e da industrialização.

É este o cenário econômico com o qual os empreendimentos ferroviários irão se deparar no final do século XIX. Evidentemente, companhias como a CMEF, a Paulista e a Sorocabana tinham ciência de todo este volume comercial e traçaram planos para, de alguma forma, trazer para si os circuitos comerciais já estabelecidos e que certamente seriam dinamizados pelos trilhos e pelo café. É certo que as potencialidades de tal ou qual região para a cafeicultura (atividade mais rentável) tinham forte peso na decisão dos traçados; porém, vale perguntar: os acionistas destas companhias desconheciam os circuitos, rotas, produtos e caminhos já estabelecidos? Cremos que não. Vejamos algumas evidências.

Em artigo que versa sobre a Companhia Paulista de Estradas de Ferro e Navegação, Perinelli Neto evidencia, a partir dos relatórios da Diretoria desta empresa, lavrados entre 1869 e 1909, alguns dos motivos que levaram os trilhos em direção ao norte do estado, especialmente à região de Barretos. O autor demonstra que a Cia. Paulista objetivava "capturar" parte do comércio de sal e de gado existente entre Goiás, Minas Gerais, Mato Grosso e São Paulo, pois, numa das referências aos relatórios, ressalta o interesse da Paulista em drenar para si parcela considerável das rotas salineiras, viabilizando a navegação fluvial do rio

(17) As feiras de Sorocaba também abasteciam o mercado mineiro, baiano e fluminense. Cf. Chiovitti $(2003)$

(18) Cf. Tosi (2003, cap. 1).

Economia e Sociedade, Campinas, v. 20, n. 2 (42), p. 417-442, ago. 2011. 
Mogi-Guaçu (o que ocorreu entre 1890 e 1903, conforme vimos acima) ${ }^{19}$. A Cia. Paulista também planejava garantir sua atuação no histórico comércio de gado polarizado por Barretos, haja vista a exitosa influência que exerceu sobre o governo paulista para a efetuação de melhoramentos na estrada que ligava o Porto do Taboado a Jaboticabal. O objetivo desta nova rota era interromper o comércio de gado existente entre o atual Mato Grosso do Sul e Uberaba, uma vez que de lá os animais eram embarcados nas estações da $\mathrm{CMEF}^{20}$. Assim, além de se beneficiar de circuitos comerciais já estabelecidos e cada vez mais promissores, a Cia. Paulista visava também restringir as potencialidades de sua concorrente direta pelos mercados do sertão, a Cia. Mogiana.

A Cia. Mogiana, por sua vez, também tinha os seus projetos de extensão da malha ferroviária em direção a importantes centros comerciais do sertão, visando atuar no comércio de sal, de gado e demais produções que porventura viessem a atingir um maior grau de desenvolvimento. Em estudo que realizamos no passado, a partir de alguns trechos de relatórios desta companhia publicados no jornal O Nono Districto, pudemos perceber que a CMEF, ao definir o traçado da linha férrea, considerava os polos dos circuitos comerciais já estabelecidos como pontos obrigatórios de passagem, obedecendo, evidentemente, os destinos estipulados nos contratos de garantias de juros. Não é aqui necessário salientar que as novas zonas promissoras para a cafeicultura, as disputas políticas locais, os obstáculos geográficos e os nexos que envolviam a própria legitimação do Estado Nacional em distantes paragens (tributação) também pesavam neste cálculo, de modo que a CMEF, ao fim e ao cabo, por todos estes motivos, possuía uma linhatronco extremamente sinuosa e repleta de ramais e sub-ramais entre Campinas-SP

(19) "O ano de 1877 deixa um pouco mais claro o motivo de estender os trilhos até o referido vale fluvial: tenciona-se estabelecer um serviço de transporte de sal no rio Mogi-Guaçu, cujo o custo final desse produto em Uberaba seja menor do que aquele que é carreado pelos carros de boi vindos de Casa Branca, portanto, que o recolhem junto aos trilhos da Mogiana. Visando levar esse intento até o fim é que ocorre o planejamento de se estender os trilhos até Pirassununga, pois assim ficará o sal a distância apenas de dezoito a vinte quilômetros de excelente caminho, até Porto Ferreira". Cf. Perinelli Neto (2008, p. 4).

(20) Trecho de uma Ata lavrada em 1895 revela esta intenção da Cia. Paulista: "Até o presente momento essa vasta região, que tem por centro a povoação de Sant'Anna do Paranahyba, em falta de outra sahida tem exportado os productos de sua indústria, que consiste principalmente na criação do gado vaccum, pela cidade de Uberaba, de onde são encaminhados para São Paulo, ou para o centro de Minas. Basta, porém, lançar um olhar para a carta geographica da República para ver a imensa volta que é preciso fazer para vir de Sant'Anna do Paranahyba [atual Paranaíba-MS] a Uberaba, com destino aos centros povoados de Minas e São Paulo, e desde então comprehender o considerável encurtamento de distância que haverá com a ligação directa de Sant'Anna ou antes do porto do Taboado junto a confluência do rio Grande com o Paranahyba, á Villa de Jaboticabal, passando a São José do Rio Preto". (sic.) Cf: Relatório da Directoria da Companhia Paulista para a sessão de Assembléia Geral de 02 de abril de 1895. Arquivo Público do Estado de São Paulo (Perinelli Neto, 2008, p. 7-8). 
e Araguari-MG, seu ponto final, situada na divisa deste estado com Goiás ${ }^{21}$ (ver Mapa no Anexo).

$\mathrm{Na}$ verdade, as aspirações da Companhia Mogiana iam muito além do triângulo mineiro. Um projeto seriamente considerado pelos dirigentes e acionistas era a extensão dos trilhos até as margens do rio Araguaia, no Porto de Santa Leopoldina, ponto no qual alcançaria a também almejada companhia de navegação fluvial que seria organizada pelo General Couto de Magalhães, conectando-se por esta forma "todo o sul do Império com o Amazonas" (Tosi; Faleiros, 2000, p. 114). Há que se considerar que com o advento da República os planos de integração nacional e a própria capacidade política e econômica dos dirigentes de estados menos desenvolvidos (como Goiás) foram seriamente restringidos, uma vez que a capacidade de oferecer benefícios e garantias de juros aos investidores diminuiu em função da reforma tributária ${ }^{22}$. Isso talvez ajude a explicar o fato de a Cia. Mogiana nunca ter cumprido o seu "desiderato" (Tosi; Faleiros, 2000, p. 126).

Paulo Roberto de Oliveira, em estudo que versa sobre as possibilidades e vicissitudes da integração fluvial de Goiás com o Pará e da integração ferroviária com São Paulo (via CMEF), destaca que o fluxo de cargas no ramal de Catalão ${ }^{23}$ foi considerado satisfatório no início do século XX, pois o transporte de animais ("exportação") no trecho mineiro representava $24 \%$ do total da linha, e o de sal ("importação") representava $42 \%$ do total. Isso, porém, não fora suficiente para empolgar os acionistas a singrar o rio Paranaíba rumo a Goiás, e o ramal Catalão

(21) Exemplo disso são os apontamentos sobre a rota comercial do Barreirinho, que seria "capturada" pela Cia. Mogiana caso se dirigisse ao município de Sacramento-MG, como realmente aconteceu: "O Sacramento, que fica ao norte de Franca, e muito à direita de Uberaba, e que é servido pelo porto do Barreirinho, nas proximidades do Jaguara, é hoje um dos mais importantes centros do commercio do sertão. Por aquella cidade passam actualmente mais de 60.000 saccos de sal por anno, o mesmo que dizer duas terças partes do sal que consome o centro, sem contar outras mercadorias. Existem no Sacramento diversos estabelecimentos commerciaes, sendo um dos mais importantes o de Simão Caleiro que vende para o centro, além de outros gêneros, de 18 a 20 mil saccos de sal. Toda a parte de Minas que comprehende Araxá, Patrocínio, Patos, Água Suja, Carmo do Paranahyba, Bagagem, Sant'Anna, Brejo, Dores de Santa Juliana, Paracatu, Formosa, etc. e Goyaz desde a capital, Santa Luzia, Bonfim, Meia-Ponte, Villa Bella, Santa Cruz, Pouso Alto, Caldas, Rio Verde, Jaraguá, Catalão, Vaivém, Corubá e outros, fazem quase todo o seu abastecimento no Sacramento ou n'esta cidade pela via do Barreirinho". (sic.). Cf. Jornal O Nono Districto, 15 jul. 1883 (Tosi; Faleiros, 2000, p. 122).

(22) Segundo a Constituição de 1891 os impostos advindos das importações pertenceriam à União, ao passo que os impostos advindos das exportações pertenceriam aos Estados. Isto criou uma marcada assimetria entre o poder econômico de governos estaduais mais diretamente ligados à exportação de algum produto e os demais. Haja vista, por exemplo, os recursos destinados pelo estado de São Paulo para a atração de mão-de-obra estrangeira, experiência que fora muito mais tímida nos demais estados da federação.

(23) Este ramal se estendia da divisa entre o estado de São Paulo com Minas Gerais, na estação de Jaguará, até Araguari-MG, sendo composto pelas estações de Jaguará, Sacramento, Conquista, Guaxima, Engenheiro Lisboa, Paineiras, Gamma, Rodolpho Paixão, Uberaba, Mangabeira, Palestina, Burity, Irára, Sucupira, Uberabinha (atual Uberlândia), Sobradinho e Araguari. Neste trecho da linha, o comércio de café e de cereais foi sempre pouco significativo. Cf. Oliveira, P. R.. (2007, p. 59-63).

Economia e Sociedade, Campinas, v. 20, n. 2 (42), p. 417-442, ago. 2011. 
da CMEF nunca tocou o município goiano que lhe batizara. $\mathrm{O}$ autor explica que a crise econômica da década de 1890 e o peso crescente dos empréstimos internacionais obstaram qualquer possibilidade de prolongamento frente à diminuição da receita desta companhia ferroviária em função do paulatino esgotamento dos solos ocupados pela cafeicultura. Há que se considerar também que o trecho mineiro da CMEF fora sempre deficitário, o que desencorajava a expansão dos trilhos rumo a Goiás, região economicamente semelhante ao triângulo mineiro, ou seja, com predominância das atividades criatórias. Aventamos também a possibilidade de que os empréstimos internacionais só seriam subscritos em Londres (principal praça creditícia) se a CMEF anunciasse prolongamentos em direção a promissoras zonas cafeeiras, pois os riscos seriam menores do que em eventuais incursões rumo ao Brasil Central, revelando certa discricionariedade do capital financeiro internacional sobre as companhias ferroviárias.

Preterindo Goiás e os planos iniciais de prolongamento, a CMEF optou por estender os seus trilhos pela zona cafeeira do sul de Minas (Muzambinho, Guaxupé, São Sebastião do Paraíso e demais municípios da região) em face da decadência dos principais centros produtores de café tributários de sua linha (Ribeirão Preto, São Simão, Cravinhos e Amparo) verificada a partir de 1913. Cabe lembrar que a Cia. Mogiana, em função do "privilégio de zona", não tinha acesso às zonas cafeeiras do oeste paulista, região tributária da Cia. Paulista ${ }^{24}$, da Estrada de Ferro Sorocabana, da Estrada de Ferro Noroeste do Brasil e da Estrada de Ferro Araraquarense, como também de estradas de ferro de menor dimensão como a Douradense e a Estrada de Ferro de Morro Agudo ${ }^{25}$.

Em que medida esta discussão a respeito dos prolongamentos ferroviários se relaciona com nosso objeto de estudo? Ora, será mera coincidência o fato de o trecho não cafeeiro da $\mathrm{CMEF}$, no triângulo mineiro, registrar seguidos déficits operacionais? Cremos que não. Por qual motivo esta companhia ferroviária optou por desbravar as zonas mais propícias à cafeicultura no sul de Minas Gerais a despeito do prolongamento rumo a Goiás? A resposta, como veremos, liga-se às especificidades da relação entre a cafeicultura e as demais atividades agrícolas e criatórias.

\section{Especialização relativa ao nível da produção}

Neste ponto da análise somos tributários da noção de "complexo cafeeiro" desenvolvida no âmbito da Escola de Campinas. Tal como transcrevemos em nota

(24) Interessante notar que a Cia. Paulista, a despeito da pujante pecuária de Barretos, do Mato-Grosso e dos projetos iniciais de seus acionistas, também dirigiu seus esforços para estender seus tentáculos para as regiões cafeeiras além de Jaú, tais como Presidente Alves, Lençóis Paulista, Garça e Marília, em trecho conhecido como "Alta Paulista".

(25) Ver Pereira (2005) e Nunes (2005). 
na introdução deste texto, a perspectiva de Cano (1998) visa apreender a totalidade de uma formação econômica, lançando luz sobre os mecanismos e inter-relações estabelecidas no processo de acumulação de capitais. Parte da ideia de que a economia paulista operava, a partir de 1886, na base de relações capitalistas de produção, aspecto qualitativamente diferenciado em relação às formações econômicas pretéritas, tais como a cana-de-açúcar no nordeste e a mineração no interior da América Portuguesa. Ainda segundo Cano (1998), esta característica possibilitou o adensamento do mercado e uma pujante produção de alimentos, inicialmente subsidiária da produção cafeeira, pois ambas eram praticadas em conjunto, aspecto típico das relações de colonato. Segundo o autor, "tomando-se como índice 100 a produção média de 1901-06, os principais produtos evoluíram, no período 1925-30, da seguinte forma: açúcar 338, feijão 331, milho 215 , arroz 689 , algodão 509 e café 192" (Cano, 1998, p. 75). No mesmo período a população do estado de São Paulo duplicou, aumentando e impondo, sobretudo nas grandes cidades, demandas cada vez maiores à produção de alimentos, que apesar de crescente, ainda não atingira a autossuficiência.

Os dados acima expostos denotam a existência de um intenso fluxo de mercadorias agrícolas (exclusive café) no espaço interno do estado de São Paulo, e a formação de uma oferta contínua e crescente fora, segundo o autor, um dos prérequisitos para a industrialização paulista. Concordamos com tal assertiva, porém, pensamos ser necessária uma melhor qualificação de como funcionava a produção mercantil de alimentos nas regiões ocupadas pela cafeicultura. O ponto de partida deve ser a análise das relações de produção mais imediatas deste complexo econômico, isto é, as relações de trabalho travadas no campo entre fazendeiros e trabalhadores (genericamente chamados de colonos) ${ }^{26}$. Ao lavrarem escrituras de formação e trato de cafeeiros definiam-se exatamente quantos cafeeiros seriam formados e/ou tratados como também os espaços disponíveis ao plantio das demais culturas, fazendo-se necessário, evidentemente, a existência de uma fronteira agrícola em expansão. Nestes termos, à expansão da atividade nuclear (cafeicultura) corresponde um crescimento considerável dos demais plantios, sendo as fazendas de café um espaço de recorrência da policultura, tendência mais nítida nas unidades produtoras de pequeno e médio porte (referimo-nos aqui às que possuíam menos de 50.000 cafeeiros).

A despeito de literatura que aponta a ascensão social de colonos mediante a livre comercialização dos alimentos produzidos ${ }^{27}$, Faleiros desenvolve o argumento de que parcela significativa destas produções de arroz, milho, feijão, mamonas e batatas foram concentradas pelos fazendeiros, pois estes, ao definirem os termos de contrato, estabeleciam cláusulas de preferência de venda invariavelmente abaixo dos preços de mercado e taxavam sobremaneira estas

(26) Cf. Faleiros (2010)

(27) Em especial o trabalho de Holloway (1984). 
atividades, notadamente no transporte e beneficiamento, de modo que a pulverizada produção dos colonos do café, ao final do ano agrícola, encontrava-se em substanciais quantidades nas mãos dos fazendeiros. Outro mecanismo bastante difundido e que agia no mesmo sentido eram as "Vendas" (estabelecimentos comerciais) localizadas nas fazendas e nas quais, mediante a entrega de parte da produção de alimentos, os colonos adquiriam os bens necessários para a sua vida. Os adiantamentos e empréstimos liquidados com alqueires de arroz e milho também agiam no mesmo sentido, de modo que seria incorreto pensar que estes trabalhadores eram livres para negociar seu produto.

É certo que estas culturas tinham autonomia muito relativa, conforme assinalou Wilson Cano ${ }^{28}$, mas também eram capazes de garantir certo retorno aos fazendeiros, principalmente se considerarmos um cenário de rápida e intensa industrialização e correlata urbanização, criando-se um mercado de maior dimensão. Não negamos a centralidade do café no processo de acumulação, porém consideramos que, para o fazendeiro, atuar no mercado de alimentos era uma estratégia interessante, e, por isso, operacionalizaram uma série de estreitamentos de mercado aos seus subordinados na fazenda, sendo o nexo perceptível a partir das escrituras de formação e trato de cafeeiros (como ficou dito, pesquisadas por Faleiros (2010)). O ponto é que existia uma hierarquia de rentabilidades capitaneada pelo café, sobretudo pelo fato de que gerava divisas, o que não significa dizer que as demais atividades não tinham importância. Assim, a dualidade mercado interno/externo parece se desfazer sucumbindo à própria lógica dos negócios. Talvez não fizesse tanta diferença ao fazendeiro o fato de seus rendimentos estarem vinculados ao consumo de café na França ou ao consumo de arroz na metrópole paulistana, conquanto que se realizasse o valor.

Este argumento talvez explique porque as Companhias Mogiana e Paulista, num determinado momento de suas trajetórias, optaram por estender seus tentáculos às áreas com potencialidade para a produção de café, e não às paragens mais distantes de Goiás e Mato Grosso. Estas companhias, respectivamente, expandiram-se para o sul de Minas Gerais e para o oeste paulista (ramal da Alta Paulista), em detrimento dos planos de expansão citados anteriormente. A questão é: sem uma atividade de alta lucratividade em termos de preços internos, nos moldes de uma economia agroexportadora, não se verifica um processo mais amplo de diversificação e dinamização que seria atrativo (pré-condição) para investimentos de grande escala, tal como as ferrovias. Talvez por isso o Brasil

(28) "O desenvolvimento e a diversificação da agricultura paulista (exclusive café) está intimamente vinculado ao processo de desenvolvimento da cafeicultura, que se expandiu ao consolidar o sistema de colonato. (...) Essa agricultura era totalmente dependente da atividade nuclear, o café, e, portanto, tinha autonomia muito relativa”. Cf. Cano (1998, p. 71-72). 
tenha, até os dias atuais, problemas com a integração do mercado nacional ${ }^{29} \mathrm{e}$, consequentemente, disparidades regionais crescentes ${ }^{30}$.

Do ponto de vista do mercado interno para a produção de alimentos, há que se destacar a importância da cidade de São Paulo para a efetivação dos circuitos. Nos "Questionários sobre as condições da agricultura dos 173 municípios do estado de São Paulo”, realizados pelo Serviço de Inspeção e defesa agrícolas do Ministério da Agricultura, Indústria e Comércio de 1913, a capital, no quesito exportação/importação" é assim descrita: "Importa cereais, gêneros de primeira necessidade, matéria-prima para as construções, fábricas, etc. Exporta produtos manufaturados, tecidos, etc." ${ }^{, 32}$. Ainda sobre as importações, os questionários revelam que os cereais consumidos em São Paulo eram quase todos produzidos no interior e em parte nos municípios vizinhos de Cotia, Guarulhos, Itapecerica e Santo Amaro. Nestes termos, tal circuito comercial denota uma divisão do trabalho onde os municípios do interior se especializaram, no âmbito do mercado interno, na produção de alimentos, cereais por suposto, e a capital se especializou na produção de bens de consumo industrializados e materiais de construção, tais como as cerâmicas produzidas nas argilosas margens dos rios Tietê e Pinheiros. Evidentemente, se trouxermos à baila o conceito cepalino de deterioração dos termos de troca, verifica-se, a partir deste circuito - desta divisão do trabalho - uma concentração de renda na capital, construída sobre uma especialização relativa ao nível da produção.

Fernand Braudel ilumina esta questão ao definir os espaços das economias-mundo ${ }^{33}$. Segundo o autor, as economias-mundo têm um limite, um centro e são hierarquizadas. "Elas têm limites e a linha que as contorna conferemlhe um sentido, tal como as margens explicam o mar" (Braudel, 1996, p. 16). A economia-mundo implica em um centro em benefício de uma cidade e de um capitalismo já dominante, seja qual for a sua forma; e são hierarquizadas, sendo

(29) Neste ponto, ver Paula (2002, v. 1, p. 7-39).

(30) Quanto à questão dos limites da acumulação cafeeira e a expansão da ferrovia para além dos limites do estado de São Paulo, ver Tosi e Faleiros (2000)

(31) Cabe lembrar que os termos exportação e importação não se referiam exclusivamente ao comércio entre diferentes países, mas designavam quaisquer tipos de entradas e saídas ao nível municipal.

(32) Verificava-se na capital paulista desenvolvida cultura de hortaliças e verduras nas regiões de Santana, Tremembé, Carandiru, Perdizes, Água Branca, Cambuci, Ipiranga, Mooca, Cantareira, Avenida Paulista e Vila Americana. Estas produções, segundo os questionários, eram destinadas ao consumo dos próprios habitantes da metrópole. Cf. Questionários sobre as condições da agricultura dos 173 municípios do estado de São Paulo (1913, p. 448). Destacavam-se as produções de abóbora italiana, alface, tomate, chicória, pepino, cebola, couve, repolho, pimentão, alcachofra e nabo.

(33) "A economia-mundo envolve apenas um fragmento do universo, um pedaço do planeta economicamente autônomo, capaz, no essencial, de bastar a si próprio e ao qual suas ligações e trocas internas conferem certa unidade orgânica". Cf. Braudel (1996, p. 12). No caso de economias agroexportadoras, há que se considerar que se ligam a conjuntos maiores via comércio e crédito. 
esse espaço a soma de economias particulares, umas pobres, outras modestas, sendo a única relativamente rica no seu centro. Daí resultam desigualdades, diferenças de voltagem, através das quais fica assegurado o funcionamento do conjunto.

Podemos pensar, a partir destas definições, que as regiões além de Araguari-MG (no caso da Mogiana) e além de Barretos (no caso da Paulista) estavam fora dos limites das trocas, ou eram superficialmente tocadas por elas, verificando-se, a partir daí, baixo grau de integração com o centro e o recorrente atraso. A capital paulista, como vimos, exercia papel central, constituindo um conjunto de múltiplas coerências, pois as diversas zonas de uma economia-mundo estão sempre voltadas para um mesmo ponto, o centro, lugar de eleição da acumulação e onde se verifica mais claramente um processo de centralização e concentração da riqueza. Isso não implica dizer, ainda com Braudel (1996), que não se verifique em algumas cidades do interior paulista um processo de especialização restrito à esfera da produção agrícola.

Cidades-etapa rodeiam o polo a maior ou menor distância - mais respeitosamente ou menos -, associadas ou cúmplices, mais frequentemente ainda sujeitas ao seu papel secundário. Sua atividade ajusta-se à da metrópole: montam guarda ao seu redor, remetem para ela o fluxo dos negócios, redistribuem ou encaminham os bens que ela lhes confia, agarram-se ao crédito ou submetem-se a ele. (...) As metrópoles apresentam-se com um séquito, uma comitiva (...) um arquipélago de cidades, e a expressão dá a imagem (Braudel, 1996, p. 20).

Campinas, Ribeirão Preto, São Carlos, São José do Rio Preto, Sorocaba, Piracicaba, Marília, Franca, Presidente Prudente e Bauru compõem este arquipélago de cidades-etapa, especializando-se em algumas atividades produtivas necessárias para o funcionamento desde complexo econômico (bens de consumo), como também, em âmbito regional, na atividade creditícia, comercial e de investimentos nas fronteiras de expansão da cafeicultura ${ }^{34}$. Porém, o centro comanda. E o faz porque exerce a liderança sobre as atividades de exportação do café no setor financeiro e atinge alto grau de especialização para as técnicas disponíveis (industrialização). As demais regiões deste complexo econômico se especializam mais claramente na produção agrícola voltada à exportação e diversificação no que se refere à produção mercantil de alimentos (ou especialização relativa ao nível da produção), sem, contudo, atingir os mesmos patamares do centro. Tal diferenciação, que engendra o reforço das hierarquias, se explica pela especialização absoluta ao nível do crédito e da circulação (transportes).

(34) Cf. Faleiros (2007, p. 428-430). 


\section{Especialização absoluta ao nível do crédito e da circulação (transportes)}

Sobre uma produção e comércio marcadamente diversificados construiuse toda uma estrutura caracterizada por uma especialização absoluta no que se refere às formas de crédito agrícola e aos transportes. Nestes pontos da cadeia produtiva se percebe nitidamente o papel central da cafeicultura na economia paulista de então. Desde os primórdios da produção de café, passando pelo crédito pessoal (hipotecário), a figura do Comissário ganha destaque como o principal emulador dos investimentos. Sem o crédito dificilmente poderíamos imaginar a instalação desta atividade econômica no Vale do Paraíba fluminense e paulista, como também não poderíamos explicar a expansão desta atividade para o oeste paulista. Quando se observa diferentes faixas de prestamistas, tanto de comissários de grosso calibre quanto de financistas locais (designados como capitalistas), verifica-se que a maior parte de seus recursos era destinada à cafeicultura e às atividades correlatas, não apenas ao financiamento dos plantios, mas sazonalmente aos adiantamentos necessários para a efetivação das colheitas, para a aquisição de produtos citadinos, de insumos e de maquinário ${ }^{35}$. A importância do crédito é ainda mais central neste complexo econômico se pensarmos que o cafeeiro produz frutos somente a partir do quarto ano, e, ainda assim, registra-se nos anos iniciais uma baixa produtividade.

Exemplo desta modalidade de crédito são as escrituras de compra e venda de café, pesquisadas por Faleiros (2010), aonde se tinha, de fato, uma escritura de empréstimo. Mediante aos adiantamentos feitos pelos prestamistas, os fazendeiros se comprometiam a entregar sua produção, como se a empenhassem como garantia ao dinheiro sacado, apresentando aos representantes dos credores (ou aos próprios) os conhecimentos de embarques fornecidos pelas ferrovias. Assim, nestes termos, os homens do crédito iam envolvendo e dominando toda a produção cafeeira, tendência que recrudesce a partir de 1906, momento no qual se verifica uma maior presença das Casas Comerciais internacionais na cadeia do crédito. Há que se considerar também que a classificação dos grãos era feita em Santos, de modo que os produtores não tinham nenhum poder para determinar a qualidade dos grãos embarcados no interior, abrindo espaço para uma negociação amplamente favorável aos prestamistas-comerciantes, em geral, representantes do grande capital cafeeiro". Em escalas mais modestas, tratando agora dos "capitalistas" locais e do crédito direcionado à pequena cafeicultura, o que se verifica é um processo de exploração ainda mais intenso, pois os prestamistas, em função das pequenas garantias hipotecárias ofertadas por este perfil de proprietários, praticam

(35) Ver Teodoro (2006)

(36) Ver Perissinotto (1994).

Economia e Sociedade, Campinas, v. 20, n. 2 (42), p. 417-442, ago. 2011. 
taxas de juros ainda mais altas, principalmente em momentos de política econômica contracionista ${ }^{37}$.

Os "capitalistas" locais, comissários e Casas Comerciais internacionais, por sua vez, tornavam-se também reféns das estreitas possibilidades existentes para a valorização de seu capital. Em quais atividades investiriam senão na cafeicultura, nas ferrovias (cujas receitas estavam diretamente ligadas a esta atividade, como veremos), na dívida pública (atrelada à "saúde financeira" do país, também diretamente ligada ao café) ou na indústria (como mercado, no limite, era criado pela atividade cafeeira)? Assim, nestes termos, o que se percebe à época é uma especialização absoluta do ponto de vista do crédito que, na sua quase totalidade, notadamente no interior, era drenado para a cafeicultura. Por isso é difícil imaginar um fluxo crescente e contínuo de crédito disponível especificamente à produção de cereais, à pecuária e à própria indústria nascente. É justamente neste ponto que se manifesta de forma mais evidente a mazela de uma formação econômica de perfil agroexportador: o crédito da sociedade é na sua quase totalidade invertido na atividade que gera divisas.

Neste quadro, seria também difícil imaginar que os empreendimentos ferroviários se organizassem de outra forma senão em função da atividade nuclear deste complexo econômico e a partir de um amplo leque de garantias oferecidas pelo Estado. Analisemos agora mais detidamente o caso da Companhia Mogiana de Estradas de Ferro, iniciando pela composição do frete. Flávio Saes aponta que existiam diferenças tarifárias para as diversas mercadorias, sendo que a tarifa do café ascende a mais do que o dobro do que as das outras mercadorias importantes para as estradas de ferro.

Por exemplo, em 1874, o café paga 206 réis por tonelada-quilômetro de transporte, ao passo que os gêneros alimentícios (não destinados à exportação) pagam apenas 100 réis. Este diferencial se mantém no tempo, uma vez que em 1936 o café paga no máximo 480 réis por tonelada-quilômetro e os gêneros alimentícios no máximo 290 réis. Assim, portanto, o retorno por serviços semelhantes se modificava muito conforme prevalecesse um ou outro tipo de mercadoria (Saes, 1940, p. 121) ${ }^{38}$.

(37) Não é aqui a ocasião de uma maior discussão a respeito do crédito à pequena cafeicultura. Sobre este tema ver Tosi; Faleiros e Teodoro, 2007, p. 1-22).

(38) O autor, à página 124, apresenta-nos o seguinte quadro a respeito da evolução tarifária $(1874=100,00)$ :

\begin{tabular}{|l|c|c|c|}
\hline Tarifas para o transporte & 1874 & 1900 & 1936 \\
\hline Café & 100,00 & 139,80 & 223,40 \\
\hline Gêneros Alimentícios & 100,00 & 75,00 & 140,00 \\
\hline Animais & 100,00 & 152,72 & 254,54 \\
\hline Madeiras & 100,00 & 140,00 & 291,66 \\
\hline Variação de Taxa de câmbio & 100,00 & 272,04 & 627,95 \\
\hline
\end{tabular}

Embora os itens "animais" e "madeiras" apresentem uma maior evolução tarifária, esta não fora suficiente para ultrapassar o custo de frete do café em termos de toneladas por quilômetro. Em 1936 o custo de transporte de animais era de 140 réis por tonelada-quilômetro, e o de madeiras era de 151 . O custo de transporte do café era de 392 t/k. Dados da CMEF. 
A partir deste ponto o autor explica o declínio da rentabilidade das ferrovias, uma vez que na diversificação da produção paulista e de seu impacto na composição dos fretes percebe-se a prática de tarifas reduzidas, implicando em menor receita quando o café tem menor participação no total - tendência clara com o passar dos anos, sobretudo quando as estradas de ferro deixam de incorporar novas zonas à produção cafeeira, verificando-se, assim, em função do desgaste das zonas produtoras, queda da participação do café na receita total ${ }^{39}$.

As mercadorias que vêm substituir o café levam à mesma ou maior despesa (se a especialização for menor) com receita menor do que a do café. Desse modo, o menor percentual de café (mesmo que se mantenha ou eleve o valor absoluto de café transportado), provoca o aumento do coeficiente de tráfego (Saes, 1981, p. $147)^{40}$.

Tal aspecto denuncia uma especialização absoluta no que se refere ao transporte ferroviário e da principal forma de circulação de mercadorias: as estradas de ferro.

Vejamos agora como esta característica se manifestou na receita da CMEF entre 1888 e 1917. A partir da consulta aos Relatórios da Diretoria desta companhia ferroviária, especificamente ao que se refere ao volume de tráfego de passageiros e cargas, sistematizamos algumas informações e desenvolvemos os gráficos e tabelas que se seguem.

No que se refere às toneladas transportadas pela Mogiana, percebe-se no período em tela uma quantidade crescente, o que indica, evidentemente, a dinamização e o crescimento do complexo cafeeiro, que se traduz notadamente nas quantidades de café, de cereais, de materiais de construção e de animais embarcados nas estações da CMEF.

A seguir temos as curvas da quantidade total de toneladas transportadas pela CMEF, da quantidade de café e da quantidade de cereais embarcadas entre 1888 e 1917. Estas curvas revelam uma diversificação crescente da produção e consequentemente dos fretes. Observem que em 1892 a curva referente ao transporte de café acompanha muito proximamente a curva referente ao transporte total da CMEF, ao passo que em 1914 as linhas se distanciam consideravelmente, sendo o transporte total de mercadorias estimado em novecentas mil toneladas - das quais duzentas mil referem-se às sacas de café embarcadas.

(39) O autor considera também o peso crescente do endividamento internacional, que comprometia parcela significativa da receita das companhias ferroviárias, como também o reajuste das tarifas, que não acompanhou a desvalorização cambial.

(40) Coeficiente de tráfego se refere à razão entre despesas e a receita derivadas exclusivamente das operações de transporte. Assim, a um maior coeficiente de tráfego, corresponde uma menor rentabilidade. No quinquênio 1876-80 o coeficiente de tráfego da CMEF era de 55,488, e entre 1936-40 era de 79,826.

Economia e Sociedade, Campinas, v. 20, n. 2 (42), p. 417-442, ago. 2011. 
Gráfico 1

Toneladas transportadas CMEF 1888-1917

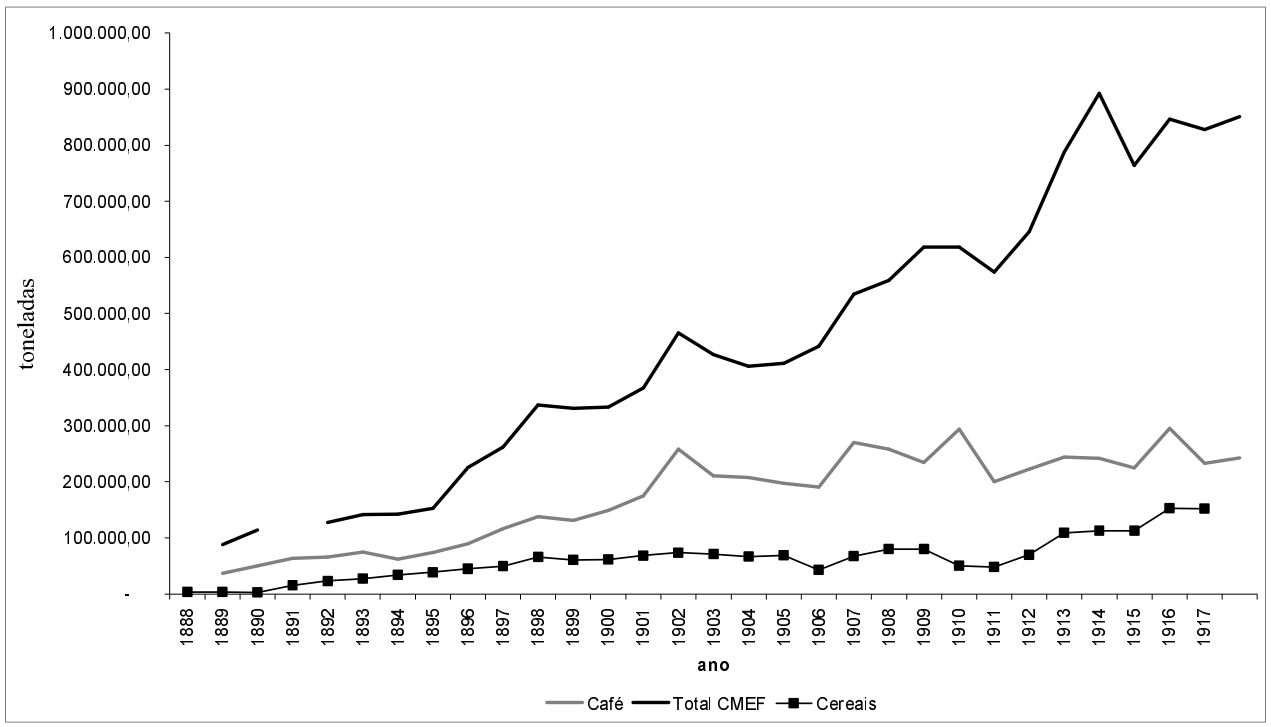

Fonte: Relatórios da CMEF entre 1888-1917.

Como tendência, a curva das toneladas de cereais (arroz, milho e feijão) transportadas acompanha, até 1895, muito proximamente a curva de café embarcado, mas, posteriormente, se distancia. Isso se explica justamente pelo plantio conjugado que apontamos posteriormente, que era praticado prioritariamente nas zonas de fronteira, justamente aquelas cortadas pela CMEF na década de 1890. Na medida em que os cafeeiros vão atingindo a idade adulta e o espaço intercafeeiro vai se tornando mais exíguo, o que se verifica é um crescimento do embarque de sacas de café em relação às quantidades de cereais embarcadas. As duas curvas voltam a se aproximar quando a CMEF captura as produções de zonas recém abertas para o café na década de 1910, tais como o sul de Minas Gerais e das zonas paulistas não exploradas anteriormente, como Morro Agudo, Orlândia, Ituverava e São Joaquim da Barra, região que constitui uma espécie de fronteira interna à zona da Mogiana ${ }^{41}$.

Como tendência geral, no tocante às toneladas embarcadas na CMEF, verifica-se um claro processo de diversificação e, consequentemente, declínio da participação relativa do café. Tal tendência pode ser verificada na Tabela 1, a seguir.

(41) Principalmente com a expansão dos trilhos rumo a Igarapava e com a construção da Estrada de Ferro Morro Agudo. Ver o trabalho de Pereira (2005). 
Tabela 1

Toneladas embarcadas nas estações da CMEF

\begin{tabular}{|c|c|c|c|c|c|c|c|c|c|}
\hline \multicolumn{10}{|c|}{ Toneladas } \\
\hline \multirow[t]{2}{*}{ Ano } & \multirow[t]{2}{*}{ Café } & \multicolumn{4}{|c|}{ Cereais } & \multirow{2}{*}{$\begin{array}{l}\text { Animais } \\
\text { (cabeças) }\end{array}$} & \multirow{2}{*}{$\begin{array}{c}\text { Total } \\
\text { CMEF }\end{array}$} & \multirow{2}{*}{$\begin{array}{c}\text { Café/ } \\
\text { Total x } \\
100\end{array}$} & \multirow{2}{*}{$\begin{array}{c}\text { Cereais/ } \\
\text { Total } \mathrm{x} \\
100\end{array}$} \\
\hline & & Arroz & Feijão & Milho & Cereais & & & & \\
\hline 1888 & $36.765,32$ & & & & $3.421,10$ & 12.673 & $87.927,14$ & 41,81 & 3,89 \\
\hline 1889 & $50.658,35$ & & & & $3.663,15$ & 22.781 & $113.926,53$ & 44,47 & 3,22 \\
\hline 1890 & $63.912,77$ & & & & $2.706,84$ & 16.022 & & & \\
\hline 1891 & $65.873,85$ & & & & $15.635,14$ & 23.984 & $127.907,75$ & 51,50 & 12,22 \\
\hline 1892 & $74.843,70$ & & & & $23.361,10$ & 24.965 & $141.768,60$ & 52,79 & 16,48 \\
\hline 1893 & $61.956,40$ & & & & $27.310,41$ & 52.416 & $142.695,11$ & 43,42 & 19,14 \\
\hline 1894 & $73.901,28$ & & & & $33.965,37$ & 29.015 & $152.624,20$ & 48,42 & 22,25 \\
\hline 1895 & $89.460,14$ & & & & $38.701,17$ & 23.618 & $225.720,12$ & 39,63 & 17,15 \\
\hline 1896 & $116.051,00$ & & & & $44.712,99$ & 7.099 & $262.124,63$ & 44,27 & 17,06 \\
\hline 1897 & $137.816,75$ & & & & $49.834,63$ & 14.152 & $336.811,25$ & 40,92 & 14,80 \\
\hline 1898 & $131.032,71$ & & & & $66.091,31$ & 21.720 & $330.842,82$ & 39,61 & 19,98 \\
\hline 1899 & $148.773,63$ & & & & $60.607,97$ & 31.144 & $332.871,48$ & 44,69 & 18,21 \\
\hline 1900 & $174.480,79$ & & & & $61.530,00$ & 36.536 & $367.491,55$ & 47,48 & 16,74 \\
\hline 1901 & $257.964,29$ & & & & $68.597,44$ & 30.057 & $465.361,60$ & 55,43 & 14,74 \\
\hline 1902 & $210.400,06$ & & & & $73.668,48$ & 47.500 & $427.096,06$ & 49,26 & 17,25 \\
\hline 1903 & $207.423,69$ & & & & $71.307,96$ & 53.305 & $406.127,26$ & 51,07 & 17,56 \\
\hline 1904 & $197.657,00$ & & & & $66.429,64$ & 47.111 & $411.004,87$ & 48,09 & 16,16 \\
\hline 1905 & $190.638,00$ & & & & $68.930,14$ & 51.931 & $441.749,97$ & 43,16 & 15,60 \\
\hline 1906 & $269.612,48$ & & & & $42.938,05$ & 95.530 & $534.239,16$ & 50,47 & 8,04 \\
\hline 1907 & $257.922,00$ & & & & $67.568,90$ & 75.996 & $558.753,06$ & 46,16 & 12,09 \\
\hline 1908 & $234.884,96$ & & & & $79.991,08$ & 65.873 & $618.467,58$ & 37,98 & 12,93 \\
\hline 1909 & $293.812,06$ & & & & $79.991,08$ & 65.873 & $618.467,58$ & 47,51 & 12,93 \\
\hline 1910 & $200.554,30$ & $35.158,36$ & $9.414,62$ & $6.184,04$ & $50.757,02$ & 84.392 & $573.627,75$ & 34,96 & 8,85 \\
\hline 1911 & $222.669,51$ & $31.228,26$ & $9.730,15$ & $7.407,93$ & $48.366,34$ & 94.701 & $645.885,77$ & 34,48 & 7,49 \\
\hline 1912 & $243.812,91$ & $48.108,67$ & $10.205,97$ & $11.549,65$ & $69.864,29$ & 136.787 & $787.289,98$ & 30,97 & 8,87 \\
\hline 1913 & $241.872,41$ & & & & $109.022,01$ & 110.672 & $892.204,13$ & 27,11 & 12,22 \\
\hline 1914 & $224.846,18$ & & & & $113.033,28$ & 84.847 & $764.005,80$ & 29,43 & 14,79 \\
\hline 1915 & $295.278,53$ & & & & $112.950,57$ & 119.831 & $846.401,10$ & 34,89 & 13,34 \\
\hline 1916 & $233.444,75$ & & & & $152.589,00$ & 225.071 & $828.073,01$ & 28,19 & 18,43 \\
\hline 1917 & $242.644,40$ & & & & $151.942,37$ & 265.040 & $850.893,12$ & 28,52 & 17,86 \\
\hline
\end{tabular}

Fonte: Relatórios da CMEF entre 1888-1917. A coluna "Total CMEF" se refere à soma total das mercadorias transportadas, englobando materiais de construção, sal, toucinho, tecidos, cervejas, vinho, aguardente, açúcar, borracha, fumo, produtos diversos, couros e algodão.

Observe nas duas últimas colunas a participação percentual do café e dos cereais em relação ao total. Corroborando a tendência já exposta, a participação do café é decrescente entre 1888 e 1917, ainda que se note que as quantidades embarcadas são tendencialmente crescentes. Já a quantidade de cereais embarcada nas estações é também crescente, porém, não conseguimos perceber uma 
tendência decrescente em termos de participação relativa. Interessante notar que em 1888 foram embarcadas $3.421,10$ toneladas de cereais, e, em 1917 , $151.942,37$, corroborando a tese da especialização relativa ao nível da produção expressa anteriormente. A quantidade de animais embarcados, notadamente gado, também é crescente; porém, como veremos adiante, em termos de receita, foram pouco significantes. Há que se frisar a considerável redução do número de cabeças embarcadas entre 1896 e 1898, um reflexo direto da atuação da Cia. Paulista além de Barretos com vistas à captura de rebanhos do Mato Grosso e de Goiás (que anteriormente eram "tocados" para Uberaba), porém a CMEF, ao inaugurar as estações de São Pedro de Uberabinha (atual Uberlândia) e Araguari, reverte esta tendência decrescente e traz para si, definitivamente, parcela significativa do comércio de gado de Goiás. Daí o aumento crescente no número de animais embarcados na CMEF, principalmente nos anos da Primeira Guerra Mundial.

Passemos agora à análise dos dados referentes à receita da CMEF. Neste quesito os relatórios não discriminam separadamente a receita oriunda do transporte de cereais, alocando-os em conjunto com os demais produtos, como podemos observar no gráfico abaixo posicionado:

Gráfico 2

Receita CMEF, 1888-1917

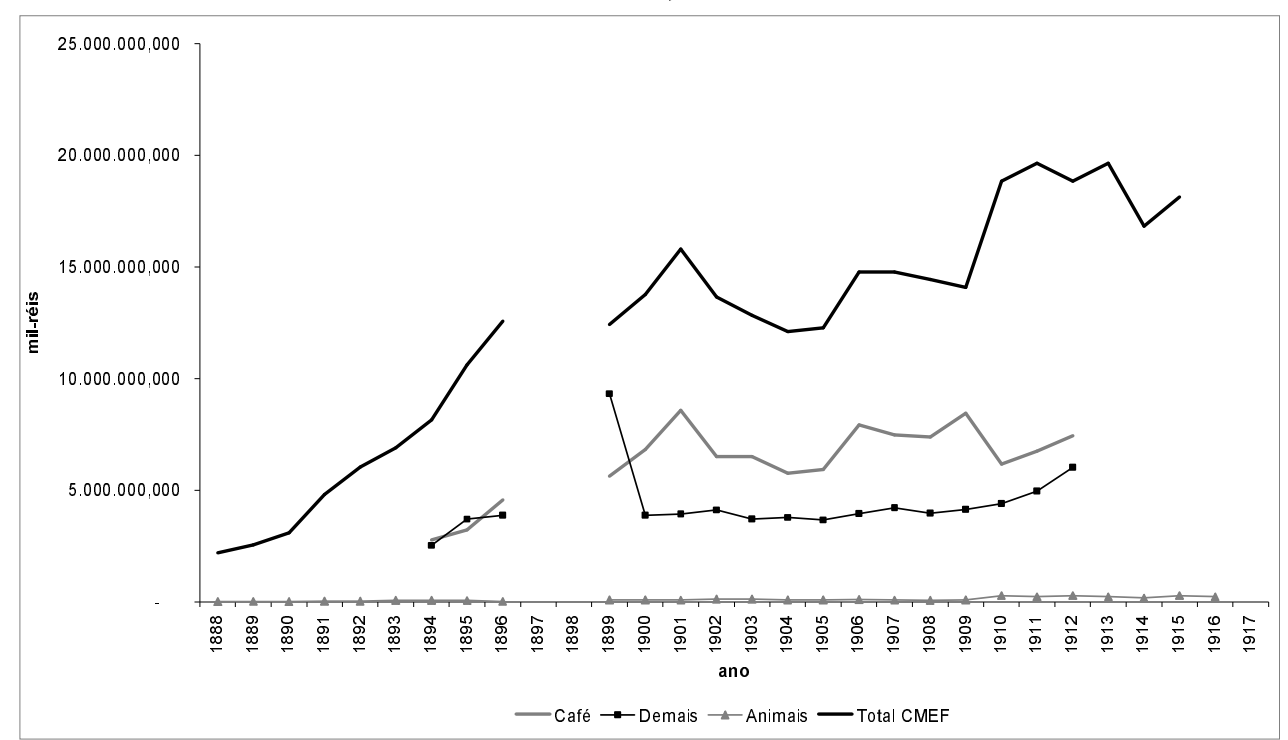

Fonte: Relatórios da CMEF entre 1888-1917.

Embora se registre uma tendência decrescente em relação às quantidades totais transportadas, o que se verifica, em termos de receita, é que o café continuou tendo uma participação decisiva com o passar dos anos. É possível perceber que, para os anos nos quais dispomos de dados, as curvas da receita total e da receita 
oriunda do café descrevem trajetórias similares, revelando, evidentemente, alto percentual de participação desta atividade no cômputo geral, ainda mais se pensarmos que a receita oriunda apenas do café é superior à soma de todas as demais, o que se nota ao comparar as duas curvas no gráfico. É possível perceber também como a receita proveniente do embarque de animais pouco soma na receita total, nunca acima de $2 \%$. Abaixo uma tabela com a participação percentual de diferentes produtos transportados em relação à receita total:

Tabela 2

Receita da CMEF 1888-1917

\begin{tabular}{|c|c|c|c|c|c|c|c|c|}
\hline \multicolumn{9}{|c|}{ Receita (mil-réis) } \\
\hline \multirow{2}{*}{ Ano } & \multicolumn{3}{|c|}{ Mercadorias } & \multirow{2}{*}{$\begin{array}{l}\text { Animais } \\
\text { Animais }\end{array}$} & \multirow{2}{*}{$\begin{array}{l}\text { Total CMEF } \\
\text { Total CMEF }\end{array}$} & \multirow{2}{*}{$\begin{array}{l}\text { Café/ } \\
\text { Total } \\
\times 100 \\
\end{array}$} & \multirow{2}{*}{$\begin{array}{c}\text { Animais/ } \\
\text { Total x } \\
100 \\
0,44\end{array}$} & \multirow{2}{*}{$\begin{array}{c}\text { Café/ } \\
\text { Demais } \\
\text { x } 100\end{array}$} \\
\hline & Café & Demais & Total & & & & & \\
\hline 1888 & & & $1.433 .764,050$ & $9.717,720$ & $2.187 .094,290$ & - & 0,72 & \\
\hline 1889 & & & $1.652 .672,180$ & $18.286,620$ & $2.541 .476,970$ & - & 0,42 & \\
\hline 1890 & & & $1.982 .044,550$ & $12.984,220$ & $3.078 .894,860$ & - & 0,67 & \\
\hline 1891 & & & $3.191 .797,780$ & $32.297,930$ & $4.806 .599,450$ & - & 0,55 & \\
\hline 1892 & & & $3.652 .424,910$ & $33.013,210$ & $6.042 .116,720$ & - & 0,96 & \\
\hline 1893 & & & $3.901 .343,910$ & $66.289,420$ & $6.886 .810,540$ & - & 0,76 & 110,03 \\
\hline 1894 & $2.777 .621,000$ & $2.524 .371,290$ & $5.301 .992,290$ & $61.864,770$ & $8.144 .714,660$ & 34,10 & 0,51 & 87,13 \\
\hline 1895 & $3.225 .856,050$ & $3.702 .145,880$ & $6.928 .001,930$ & $54.132,530$ & $10.614 .183,670$ & 30,39 & 0,18 & 117,71 \\
\hline 1896 & $4.554 .181,190$ & $3.868 .878,790$ & $8.423 .059,980$ & $22.203,860$ & $12.563 .900,110$ & 36,25 & & \\
\hline 1897 & & & - & & & & & \\
\hline 1898 & & & - & & & & 0,68 & 60,44 \\
\hline 1899 & $5.631 .145,590$ & $9.317 .556,680$ & $14.948 .702,270$ & $84.870,290$ & $12.413 .337,690$ & 45,36 & 0,62 & 175,99 \\
\hline 1900 & $6.825 .401,120$ & $3.878 .189,790$ & $10.703 .590,910$ & $85.436,200$ & $13.754 .711,080$ & 49,62 & 0,49 & 218,44 \\
\hline 1901 & $8.580 .258,420$ & $3.928 .014,460$ & $12.508 .272,880$ & $76.987,440$ & $15.799 .586,380$ & 54,31 & 0,88 & 158,15 \\
\hline 1902 & $6.499 .217,050$ & 4.109.465,380 & $10.608 .682,430$ & $120.093,310$ & $13.643 .891,680$ & 47,63 & 0,94 & 175,20 \\
\hline 1903 & $6.506 .474,350$ & $3.713 .749,040$ & $10.220 .223,390$ & $121.031,890$ & $12.833 .276,590$ & 50,70 & 0,69 & 152,56 \\
\hline 1904 & $5.759 .352,990$ & $3.775 .200,470$ & $9.534 .553,460$ & $82.915,390$ & $12.093 .649,530$ & 47,62 & 0,67 & 161,95 \\
\hline 1905 & $5.927 .614,560$ & $3.660 .189,660$ & $9.587 .804,220$ & $82.095,600$ & $12.267 .893,990$ & 48,32 & 0,73 & 200,08 \\
\hline 1906 & $7.925 .211,020$ & $3.961 .083,900$ & $11.886 .294,920$ & $108.413,970$ & $14.772 .573,610$ & 53,65 & 0,54 & 177,42 \\
\hline 1907 & $7.473 .388,880$ & $4.212 .243,570$ & $11.685 .632,450$ & $80.040,670$ & $14.766 .665,510$ & 50,61 & 0,47 & 186,02 \\
\hline 1908 & $7.380 .461,560$ & $3.967 .492,250$ & $11.347 .953,810$ & $68.012,080$ & $14.433 .714,960$ & 51,13 & 0,61 & 204,08 \\
\hline 1909 & $8.442 .031,850$ & $4.136 .540,820$ & $12.578 .572,670$ & $86.035,880$ & $14.077 .864,580$ & 59,97 & 1,45 & 140,19 \\
\hline 1910 & $6.169 .315,280$ & $4.400 .789,360$ & $10.570 .104,640$ & $273.852,550$ & $18.842 .882,310$ & 32,74 & 1,16 & 136,07 \\
\hline 1911 & $6.746 .434,630$ & $4.958 .129,710$ & $11.704 .564,340$ & $227.469,470$ & $19.633 .722,390$ & 34,36 & 1,45 & 123,50 \\
\hline 1912 & $7.436 .998,790$ & $6.021 .774,930$ & $13.458 .773,720$ & $273.852,550$ & $18.842 .882,310$ & 39,47 & 1,16 & \\
\hline 1913 & & & $13.657 .802,760$ & $227.469,470$ & $19.633 .722,390$ & - & 1,04 & \\
\hline 1914 & & & $11.378 .709,250$ & $175.411,820$ & $16.821 .850,740$ & - & 1,54 & \\
\hline 1915 & & & $13.090 .602,780$ & $278.783,520$ & $18.117 .493,970$ & - & & \\
\hline 1916 & & & & $225.071,000$ & & & & \\
\hline 1917 & & & & & & & & \\
\hline
\end{tabular}

Fonte: Relatórios da CMEF entre 1888-1917. 
A participação do café na receita total, que inclui as demais mercadorias, nunca foi inferior a $30 \%$, sendo, em alguns anos, superior a $50 \%$ - e próxima a $60 \%$, em 1909. Isso se explica não só pelas quantidades crescentes embarcadas, mas também em função do diferencial do valor do frete, tal como vimos anteriormente. Este fato indica a centralidade da cafeicultura para a estrutura ferroviária de então, a despeito de uma notável diversificação produtiva verificada nas terras do café, como vimos em tópico anterior. Infelizmente não dispomos de dados para o período posterior a 1917, porém, com esta configuração de receita não é difícil imaginar que a CMEF enfrentaria dificuldades econômicas crescentes com a paulatina perda de produtividades dos cafeeiros plantados na zona por ela cortada, o que já se manifestou na década de vinte.

Tal dependência das companhias ferroviárias em relação ao café se explica pela própria lucratividade desta atividade, capaz de suportar tarifas superiores às demais atividades, destinadas principalmente ao mercado interno. Há que se pensar, neste ponto, nos ganhos cambiais auferidos pelos cafeicultores e comerciantes nos momentos de desvalorização da moeda, ao passo que, nestes mesmos momentos, as estradas de ferro enfrentavam um abrupto aumento de suas despesas, dado o alto coeficiente de importação das mesmas. Nestes termos, por mais que se verificasse um processo de diversificação no âmbito da produção, que gerava considerável receita às ferrovias, não se pode negar a especialização absoluta que as caracterizava ao nível da circulação. Sim, elas só seriam viáveis se "catassem café" 42 nas zonas produtoras do interior. O próprio processo de decadência das ferrovias paulistas nas décadas de 1940 e 1950 corrobora tal assertiva.

\section{Considerações finais}

Esta reflexão orientou-se por um esforço de síntese entre as tradicionais referências ao estudo da cafeicultura e os novos estudos sobre o café, que têm privilegiado uma abordagem mais específica das localidades que compuseram o chamado complexo cafeeiro. O presente artigo buscou construir esta síntese trabalhando com duas categorias, quais sejam: "especialização relativa ao nível da produção" e "especialização absoluta ao nível do crédito e da circulação (transportes)"; estas se referem, respectivamente, ao potencial dinamizador e diversificador criado pela cafeicultura ainda no plantio das árvores e à criação de demanda que deu sentido a um processo de integração do mercado interno a partir da economia paulista, e uma modalidade de financiamento voltada quase que exclusivamente para formas de crédito à atividade nuclear, fato que estabeleceu vinculação imediata entre companhias ferroviárias e produção cafeeira.

(42) Alusão à expressão "estradas cata-café", cunhada por Odilon Nogueira de Matos em Café e ferrovias (1974). 
Tal esforço se justifica em função dos limites presentes nas apreciações em que a compreensão aparece fragmentada ora pela análise do papel do crédito, ora pela análise da produção. Mesmo considerando que o fenômeno seja caracterizado por matizes e diferenciações em suas partes constitutivas, é importante destacar que o entendimento acerca dos circuitos de produção, circulação e consumo da e na economia cafeeira não podem ser vistos por meio de focos exclusivamente voltados para a esfera da produção de café. Sua complexidade começa na medida em que se consideram as formas de oferta e de procura do crédito, bem como as características dos serviços de transporte associados e que, a partir daí, sejam criadas condições para identificar a presença dos grupos sociais e a natureza dos interesses desses segmentos da sociedade e, se for possível, precisar taxa de acumulação proporcionada pela atividade nuclear e pelos outros negócios a ela acoplados.

Aqui, optou-se por uma perspectiva de conjunto, considerando a esfera da produção paulista como altamente diversificada no que se refere à produção agrícola e, posteriormente, industrial. Porém, há que se buscar o sentido desta diversificação na estrutura e na dinâmica do complexo cafeeiro que, em função de seu vigor explicativo, permanece como baliza teórica que deve orientar os novos estudos sobre o café e sobre São Paulo na República Velha.

\section{Bibliografia}

ALENCASTRO, Luiz Felipe de. O trato dos viventes. Formação do Brasil no atlântico sul. São Paulo: Cia das letras, 2000.

ARARAQUARA. Álbum de Araraquara para o ano de 1915. Araraquara: Câmara Municipal de Araraquara, 1915.

BENINCASA, Vladimir. Velhas fazendas. Arquitetura e cotidiano nos Campos de Araraquara. 1830-1930. São Paulo: Edufscar/Imprensa Oficial, 2003.

BRAUDEL, Fernand. Civilização material, economia e capitalismo. Séculos XV-XVIII. O Tempo do Mundo. São Paulo: Martins Fontes, 1996.

CAMARGO, José Francisco de. Crescimento da população no estado de São Paulo e seus aspectos econômicos. São Paulo: FIPE, 1981. v. II e III.

CANO, Wilson. Raízes da concentração industrial em São Paulo. 4. ed. Campinas: IE/Unicamp, 1998.

CHIOVITTI, Nanci Marti. Discursos do progresso: Sorocaba e o fim das feiras de muares. Campinas: IFCH/Unicamp, 2003.

DI CREDDO, Maria do Carmo S. Terras e índios no Vale do Paranapanema. São Paulo: Arte \& Ciência, 2003.

DOMINGUES NETO, Hilário. Singrando o Mogi-Guaçu: um estudo sobre a formação de um mercado interno regional (1883-1903). Dissertação (Mestrado)-FCL-UNESP, Araraquara, 2001.

Economia e Sociedade, Campinas, v. 20, n. 2 (42), p. 417-442, ago. 2011. 
FALEIROS, Rogério Naques. Ferrovia, café e imigrantes: o trinômio da transformação. Franca: 1887-1902. Monografia (Conclusão de Curso)-FHDSS-Unesp, Franca, 1999.

. Fronteiras do café; fazendeiros e "colonos" no interior paulista: 1917-1937. Tese (Doutorado)-Instituto de Economia, Unicamp, Campinas, 2007.

Homens do café: Franca 1880-1920. Ribeirão Preto: Holoes, Editora; São Paulo: Fapesp, 2008.

. Fronteiras do café: fazendeiros e "colonos" no interior paulista. Bauru: Edusc; São Paulo: Fapesp, 2010.

FERRÃO, André Argolo. Arquitetura do café. Campinas: Editora da Unicamp; São Paulo: Imprensa Oficial do Estado de São Paulo, 2004.

FRAGOSO, João Luís. Sistemas agrários em Paraíba do Sul (1850-1920). Um estudo de relações não capitalistas de produção. Dissertação (Mestrado)-Universidade Federal do Rio de Janeiro-UFRJ, Rio de Janeiro, 1983.

; FLORENTINO, Manolo. O arcaísmo como projeto: mercado atlântico, sociedade agrária e elite mercantil no Rio de Janeiro, 1790-1840. Rio de Janeiro: Sette Letras, 1998.

HOLANDA, Sérgio Buarque de. Caminhos e fronteiras. São Paulo: Cia das Letras, 1994.

HOLLOWAY, Thomas. Imigrantes para o café: café e sociedade em São Paulo 18861934. Rio de Janeiro: Paz \& Terra, 1984.

LENHARO, Alcir. As tropas da moderação. O abastecimento da Corte na formação política do Brasil: 1808-1842. Rio de Janeiro: Secretaria Municipal de Cultura, 1993.

LINHARES, Maria Yeda; SILVA, Francisco C. T. da. História da agricultura brasileira. São Paulo: Brasiliense, 1980.

MATOS, Odilon Nogueira de. Café e ferrovias: a evolução ferroviária de São Paulo e o desenvolvimento da cultura cafeeira. São Paulo: Alfa-Ômega, 1974.

MESSIAS, Rosane Carvalho. O cultivo de café nas bocas do sertão paulista. Mercado interno e mão de obra no período da transição 1830-1888. São Paulo: Unesp, 2003.

MINISTÉRIO DA AGRICULTURA, INDÚSTRIA E COMÉRCIO. Questionários sobre as condições da agricultura dos 173 municípios do estado de São Paulo. Realizado pelo Serviço de Inspeção e Defesa Agrícolas do Ministério da Agricultura, Indústria e Comércio. Rio de Janeiro: Typ. do Serviço de Estatistica, 1913.

NUNES, Ivanil. Douradense: a agonia de uma ferrovia. São Paulo: Annablume; Fapesp, 2005.

OLIVEIRA, Flávia Arlanch de. Faces da dominação da terra (Jaú 1850-1910). Marília: Unesp; São Paulo: Fapesp, 1999.

OLIVEIRA, Lélio Luiz de. Heranças guardadas e transições ponderadas. História Econômica do interior paulista. Franca: Unesp-FHDSS; UNI-Facef, 2006.

OLIVEIRA, Mônica Ribeiro de. Cafeicultura mineira: formação e consolidação. 18091870. In: SEMINÁRIO SOBRE A ECONOMIA MINEIRA, 9, 2000. Anais... 
OLIVEIRA, Paulo Roberto de. Entre rios e trilhos: as possibilidades de integração econômica de Goiás na Primeira República. Franca: FHDSS/Unesp, 2007.

PAULA, João Antônio de. O mercado e o mercado interno no Brasil: conceito e história. História Econômica \& História de Empresas, v. 1, 2002.

PEREIRA, Reginaldo de Oliveira. Nas margens da Mogiana. As repercussões da cafeicultura no município de Orlândia (1901-1940). Dissertação (Mestrado)-FHDSSUnesp, Franca, 2005.

PERINELLI NETO, Humberto. Era a Paulista uma ferrovia cata-café? Apontamentos sobre o comércio de gado e as ferrovias em São Paulo. Histórica. Revista Eletrônica do Arquivo Público do Estado de São Paulo, n. 32, 2008.

PERISSINOTTO, Renato M. Classes dominantes e hegemonia na República Velha. Campinas: Editora da Unicamp, 1994.

SAES, Flávio Azevedo Marques de. As ferrovias em São Paulo 1870-1940. São Paulo: Hucitec, 1981.

SANTOS, Ronaldo Marcos dos. Resistência e superação do escravismo na Província de São Paulo (1885-1888). São Paulo: IPE/USP, 1980.

SCHWARTZ, Stuart B. Segredos internos: engenhos e escravos na sociedade colonial: 1550 - 1835. São Paulo, Companhia das Letras, 1988.

SILVA, César Múcio. Processos-crime. Escravidão e violência em Botucatu. São Paulo: Alameda, 2004.

TEODORO, Rodrigo da Silva. O crédito no mundo dos senhores do café. Dissertação (Mestrado)-Instituto de Economia, Unicamp, Campinas, 2006.

TOSI, Pedro Geraldo. Capitais no interior: Franca e a história da indústria coureirocalçadista (1860-1945). Franca: FHDSS-Unesp, 2003.

; FALEIROS, Rogério Naques. Nas fronteiras do capitalismo: a Mogiana e os (des)caminhos da expansão ferroviária. Locus: Revista de História, Juiz de Fora, v. 6, n. 2, 2000.

; _ _ TEODORO, Rodrigo da Silva. Crédito e pequena cafeicultura no Oeste Paulista. Franca: 1890-1914. Revista Brasileira de Economia, v. 61, p. 1-22, 2007.

TRUZZI, Oswaldo Mário Serra. Fontes estatístico-nominativas da propriedade rural em São Carlos (1873-1940). São Carlos: Edufscar, 2004.

ZEMELLA, Mafalda. O abastecimento da capitania das Minas Gerais no século XVIII. São Paulo: USP/FFCL, 1951. 


\section{Anexo}

Mapa da CMEF. Linha tronco e principais ramais

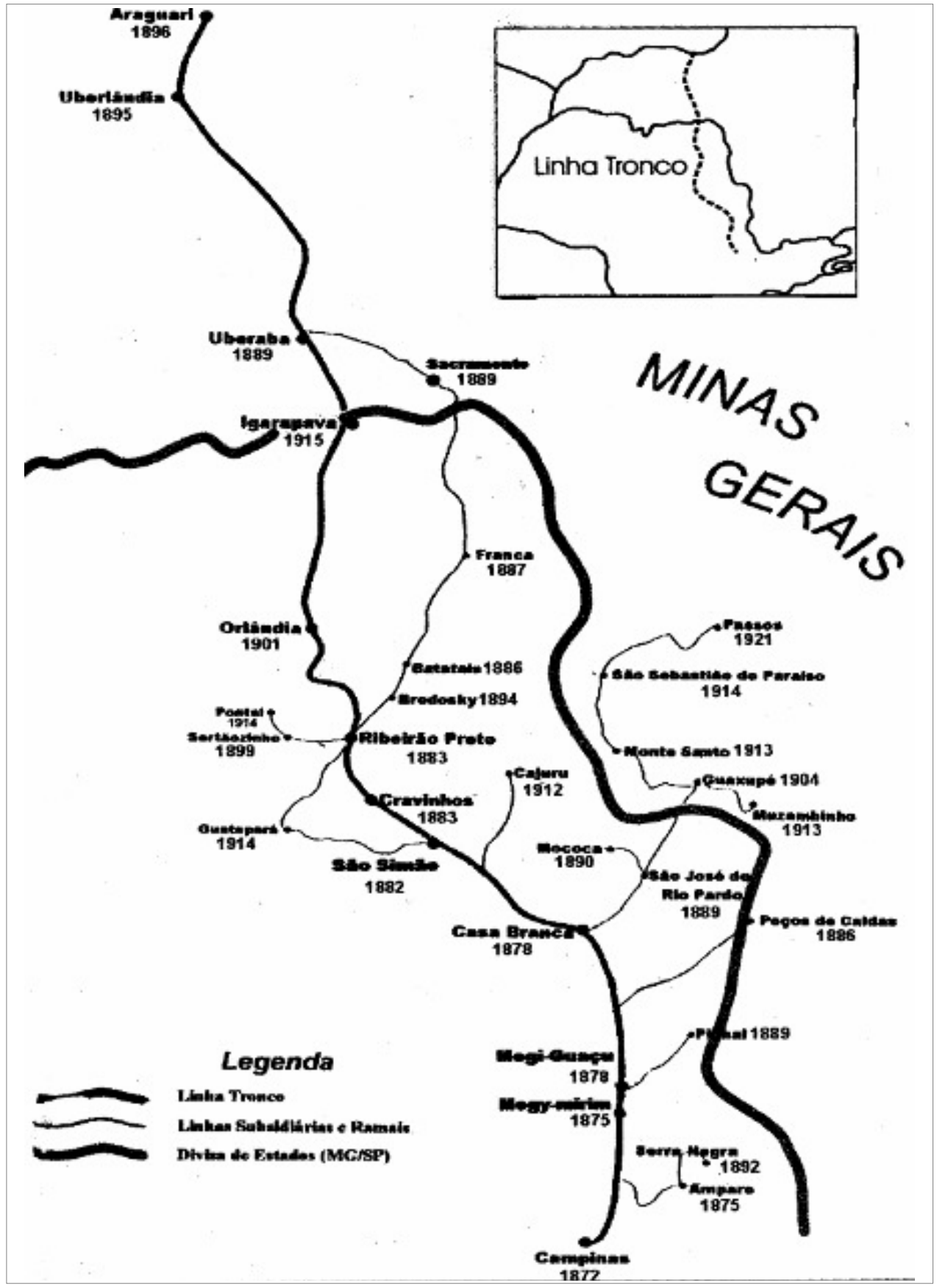

Fonte: Faleiros (1999). 